\title{
A crossectional study of Rajayakshma symptoms in HIV positive patients
}

\author{
Research Article
}

\section{Saurabh Bajirao Kadam¹, Shital Rahul Rasane ${ }^{2 *}$, Atul Viraj Wadagale ${ }^{3}$}

1. Assistant Professor, 2. Associate Professor, Department of Ayurved Samhita Siddhanta, Dr D.Y. Patil College of Ayurved \& Research Centre, Pimpri Pune. Dr. D. Y. Patil Vidyapeeth, Pune, Maharashtra, India. 3. Lecturer-cum-Statistician, Department of Community Medicine, Vilasrao Deshmukh Government Medical College, Latur, Maharashtra, India.

\begin{abstract}
Background: According to Ayurveda, the HIV Symptoms may be correlated with Rajayakshama (Kshaya). The Symptoms, causative factors and treatment for the latter were found mentioned in many ancient Ayurvedic texts. Present study was aimed to assess the correlation of Rajayakshama symptoms described in Charak Samhita and symptoms seen in HIV positive patient. Material and Method: Present study was a Cross-sectional Survey Study, conducted in patients of 25 - 50 years age group, irrespective of sex, religion, economic \& marital status, diagnosed patients of HIV antibody test positive minimum 2 year ago. Results: Maximum number of HIV patient was from $31-40$ years age group (67\%). Majority of HIV patients were Female (81\%). $53 \%$ patients' were HIV Antibody Test Positive more than 2 year ago \& $47 \%$ patients were more than 10 year ago. $97 \%$ patients were on antiretroviral therapy Medication and only 3\% patients were not given antiretroviral therapy Medication. Ansatapa, Jwara and Parshwashula were observed in all 100\% patient. other symptoms Shirashula (99\%); Aruchi (96\%); Swarabheda (94\%); Shwasa (87\%); Kasa(60\%), Atisara(51\%); Raktasthivana (12\%) and Raktavamana (4\%). 69\% cases were observed with 8-11 symptoms of Rajayakshma. 30\% cases had 5-7 symptoms and only 1\% cases had 1- 4 symptoms of Rajayakshma. Conclusion: this disease is more related to mental status of the person. Following Dinacharya, Rutucharya, Sadvrittapalana, Aachararasayana etc. explained in Ayurveda will definitely help in treating AIDS and improving patient's health.
\end{abstract}

Key Words: Ayurveda, AIDS, HIV, Rajayakshma.

\section{Introduction}

Medical sciences identify new diseases every year. But at similar junctures, Ayurveda views and responds to it on the basis of the changes in signs, symptoms and corresponding change in Samprapti, Dosha Dushya Sammurchana is used for the treatments of various diseases at different Vyadhi Avastha in Ayurveda. Knowledge of Samprapti is essential for treating the disease as early as possible by breaking the pathogenesis at starting stage (1).

According to Ayurveda, the HIV Symptoms may be correlated with Rajayakshama (Kshaya) (2). The Symptoms, causative factors and treatment for the latter were found mentioned in many ancient Ayurvedic texts like, Charaka Samhitha, Bhavaprakasha, Vaidyachintamani and Chakradatta etc. Kshaya Roga is mentioned in all Ayurveda texts as name of Rajayakshma. In this they explained that all Rasadi

* Corresponding Author:

Shital Rahul Rasane

Associate Professor, Department of Ayurved Samhita

Siddhanta, Dr D.Y. Patil College of Ayurved \&

Research Centre, Pimpri Pune- 411018,

Dr. D. Y. Patil Vidyapeeth, Pune, Maharashtra. India.

Email Id: shital.rasane@,dpu.edu.in
Sapta Dhatu goes to harass one by one either in ascending order or descending.

AIDS, an acronym for Acquired Immune Deficiency Syndrome, one of the major health problems encompassing the whole world in a vice like grip, is caused by a Retrovirus called $\mathrm{Human}$ Immunodeficiency Virus (HIV). Unlike other epidemics AIDS falls heavily on young adults in their prime, posing a great challenge in the areas of health, social and economic development. Today it is clear that virtually every practicing physician in the country and worldwide will be required to have degree of familiarity with the workup, diagnosis, management and specific treatment of HIV infected individuals.

Ayurveda text never had being edited since 5000 yrs, when it had written. In present time many more new diseases adding in our life. It is curing by Ayurveda medicines with the help of its Siddhant, Symptoms, Agni etc. This is specialty of Ayurveda that it can cure diseases of any type and give better life of diseased person without having any harm, if it will be taken with proper methods and time. Present study was aimed to assess the correlation of Rajayakshama symptoms described in Charak Samhita and symptoms seen in HIV positive patient. 


\section{Materials and Methods}

Present study was a Cross-sectional Survey Study, conducted in Department of Ayurveda Samhita \& Sidhhanta, Dr D.Y. Patil college of Ayurved \& research centre Pimpri, India. Study duration was of 2 years (July 2018 to June 2019). Study was approved by institutional ethical committee.

\section{Inclusion Criteria:}

- Age group of 25 - 50 years irrespective of sex, religion, economic \& marital status, diagnosed patients of HIV antibody test positive minimum 2 year ago.

\section{Exclusion Criteria:}

- Patients having HIV antibody test positive but not willing to this survey.

Questionnaire was prepared to assess the presence symptoms of Rajayakshma in HIV. positive patient and to find out Ayurvedic perspective of AIDS Questionnaires were filled by collecting inputs from the HIV positive patients which includes a consent form duly signed by them. Compiled references from Ayurvedic Compendia of Symptoms of Rajayakshma (3) were used for assessment of relation of symptoms of HIV Positive (4) Patient with Ayurvedic perspective.

Data was collected and compiled using Microsoft Excel, statistical analysis was done using descriptive statistics.

\section{Observations and Results}

In this study, the maximum number of HIV patient was in age group between 36-40 years and 31-35 year i.e., about $67 \%$.

Table 1: Classification According to Age

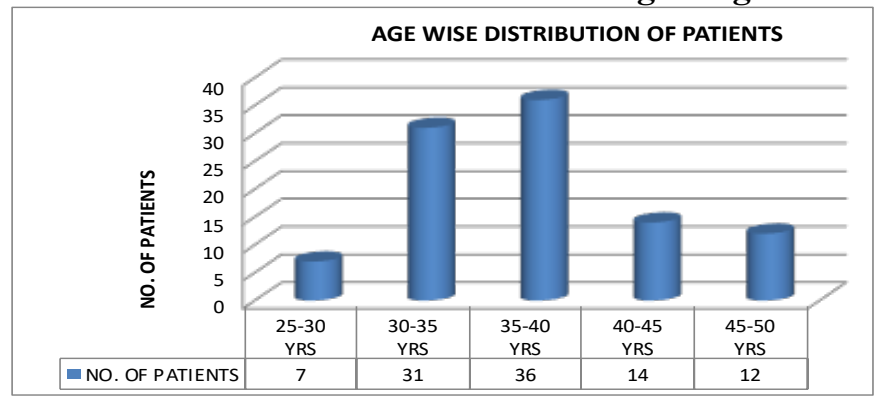

Majority of HIV patients i.e., $81 \%$ were Female most of them were widows.

Table 2: Classification According to Gender GENDERWISE DISTRIBUTION OF PATIENTS

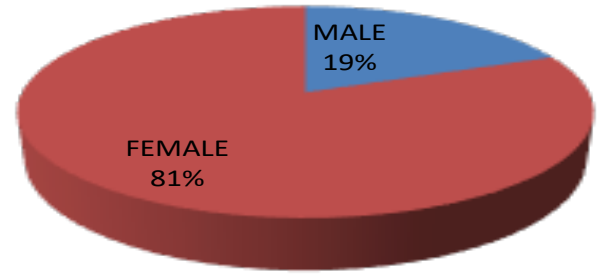

Among observed data, $53 \%$ patients' were HIV. Antibody Test Positive more than 2 year ago \& $47 \%$ patients were more than 10 year ago.

\section{Table 3: Classification According to Duration from} HIV. Antibody Test Positive.

Diagnosed Time

Duration

Number of Patients

\begin{tabular}{c|c}
2 to 10 years & 53 \\
Above 10 years & 47 \\
\hline Total & 100
\end{tabular}

In this study, $97 \%$ patients were on antiretroviral therapy Medication and only 3\% patients were not given antiretroviral therapy Medication.

Table 4: Classification according to antiretroviral therapy Treatment Distribution among Subject

\section{Antiretroviral Therapy Treatment wise Distribution Of Patients}

- ONMEDICATION INOTON MEDICATION

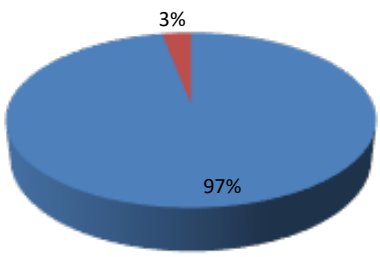

Ansatapa, Jwara and Parshwashulathese three symptoms were observed in all $100 \%$ patient. $99 \%$ patient with Shirashula; 96\% patient with Aruchi; $94 \%$ patient with Swarabheda; 87\% patient with Swasa; 60\% patients with Kasa Symptom; $51 \%$ patients with Atisara; $12 \%$ patients history of Raktasthivana and only $4 \%$ patients history of Raktavamana.

Table 5: Classification According to Observed Rajayakshama Symptoms

Observed Symptoms Symptomatic Asymptomatic

\begin{tabular}{|l|c|c|}
\hline Kasa & 60 & 40 \\
\hline Ansatapa & 100 & 0 \\
\hline Swarabheda & 94 & 6 \\
\hline Jwara & 100 & 0 \\
\hline Parshwashul & 100 & 0 \\
\hline Sirshula & 99 & 1 \\
\hline Raktasthivan & 12 & 88 \\
\hline Raktawaman & 4 & 96 \\
\hline Shwas & 87 & 13 \\
\hline Atisara & 51 & 49 \\
\hline Aruchi & 96 & 4 \\
\hline
\end{tabular}

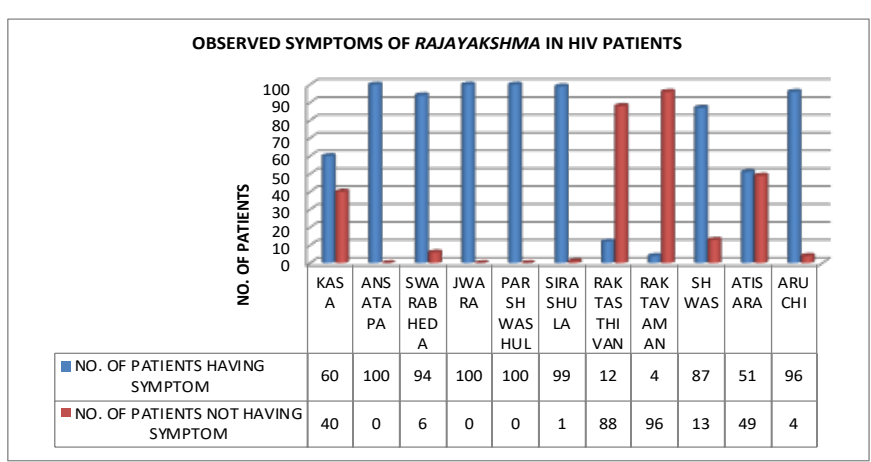


In this study, $69 \%$ cases were observed with 8 to 11 symptoms out of 11 symptoms of Rajayakshma. $30 \%$ cases in between 5 to 7 symptoms and only $1 \%$ cases in between 1 to 4 symptoms of Rajayakshma.

\section{Table 6: Total No. of Rajayakshma Symptoms Observed in Patient}

No. of Rajayakshma Symptoms Observed in Patient Number of patients

\begin{tabular}{|c|c|}
\hline 1 to 4 & 1 \\
\hline 5 to 7 & 30 \\
\hline 8 to 11 & 69 \\
\hline Total No. of Patient & 100 \\
\hline
\end{tabular}

\section{Rajayakshma Symptoms}

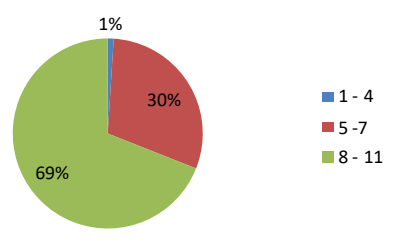

In this study, 69\% cases were observed Maximum symptoms of Rajayakshma that was more than 7 out of 11 Symptoms. In Maximum symptoms, Rajayakshma 69\% symptoms resembling with symptoms observed in HIV positive patient in total volume of patients decided in patient of Advance stage HIV infection.

\section{Table 7: Symptoms category wise Distribution}

Total No. Symptoms Observed out of 11 symptoms of Rajayakshma

Maximum symptoms (more than7) Medium symptoms (5 to 7)

Minimum symptoms (up to4)

Percentage
$69 \%$
$30 \%$
$1 \%$

\section{Discussion}

The aim behind this study was not only to compare AIDS with any disease mentioned in Ayurveda, but also to help of management and treatment of AIDS according to Ayurveda. AIDS is nontreatable disease mentioned by modern medicine. Ayurveda treated many more disease which was nontreatable. Survey part was concluded by many points as below,

-AIDS disease can't diagnose earlier because of its symptoms is much related with normal flue. At the dangerous stage this disease can be identified by its symptoms.

-Due to more awareness of AIDS by W.H.O. and government most of the patients start antiretroviral therapy plan earlier.

- This data concludes that, AIDS is more near with Rajayakshma. All 11 symptoms of Rajayakshma were seen in Advance stage HIV infection.

In present study, 36 to 40 years of age group was noted in 36. According to Ayurveda Samhita Madhyamavastha of age were starts from 30 years till 60 years. One more thing added at that time in Ayurveda Samhita that average life span mentioned 100 years. But in this era average life span is 80 years. So, middle is considered according to this statement is 31 to 40 years. For this disease middle age is very prone to affect. Other age groups were 31 to 35 years of age group (31 $\%), 41$ to 45 years $(14 \%) \& 46$ to 50 years $(31 \%)$.

In present study, female were found affected with this disease $81 \%$ while male was $19 \%$ of total volume of patient. Mostly females were found in widow condition that their husband had died due to AIDS This disease is socially not accepted due to Transmission way of HIV so, patients having fear to expose themselves in front of society.

Some diseases were very proportional to time duration they detected. AIDS is one of them in this type of diseases. Incubation period of AIDS is 2 years. \&. 2-10 years of duration of diagnosed is having peculiar symptoms of HIV or AIDS, From 2-10 years of detection period grouping most of the patient categorized 53 among 100 patients. More than 10 years of diagnosis period is very dangerous period than can be fetal too $(47 \%)$.

This disease is untreatable type of disease. Antiretroviral therapy is the only medicine provided by W.H.O. for this disease. But about this treatment expert says that these medicines do not kill the virus. Only controls growth of this virus. But this virus has special quality to change their shell so no medication effect on this virus. To improve patient's condition these medicines were provided by the government.

According to this division many of patients were having antiretroviral therapy after efforts of the government and mass education about mode of infection. Patients were following antiretroviral therapy were found 97 among 100 and only 3 patients were found who left antiretroviral therapy due many complications or normal CD4 Count.

Rajayakshma is one of the ayurveda diseases which can correlate with AIDS among 100 patients, most of them were found to have Rajayakshma symptoms. Rajayakshma symptoms were charted and searched in survey study in all patients.

Kasa is one of the symptoms found in 60 patients among whole sample of this dissertation. Ansatapa is symptom in which patient complaint pain at shoulder region with or without exertion. All the patients were complaint with this symptom. Swarbheda is included in this disease. Hoarseness of voice or any changes in voice in patients come under this category. 94 patients were complained with this symptom. Jwara is mentioned in Ayurveda as a disease but at some condition it is taken as a symptom in some disease. In Rajyakshma jwara is one of the symptoms. In present study, all the patients were found with this symptom of on and off fever. Parshvashoola is also explained in Rajayakshma as symptom i.e. Pain in back region complained by all most every patient in this survey study. About $99 \%$ of patient complained with shirashula in this survey study. Raktasthivana is one of the critical symptoms written by Ayurveda Samhita. History of Raktasthivana was seen in 12 patients. Only 4 patients were complained having symptom of Chardi. In which patient told history of Raktavamana (hematemesis). Almost all Patients were taking 
Antiemetic medicine with antiretroviral therapy medicine. So, there was error to find out chardi symptom. Shwas is explained as a disease in ayurvedic texts. But here in Rajayakshma, shwas is mentioned one of symptom. In this study 87 patients reported to have symptom breathlessness after any small work or short duration exertion. Again, Atisarais one of the diseases described in Ayurveda. Itself it is one of symptom of Rajayakshma. In survey study among 100 patients 51 were complained repeatedly loose motion with Sapichchhilam (mucous). Aruchi is mentioned Rajayakshma main symptom. Among all patients participated in study 96 were complained about Aruchi. They were not interested to eating or they were not foodie person.

In patients, 1 to 4 symptoms were found only $1 \%, 30 \%$ patients were affected with 5 to 7 symptoms of Rajayakshma \& $69 \%$ patients of HIV were found with 8 to 11 symptoms of Rajayakshma. Last category of patients i.e. 8 to 11 symptoms were observed Advance stage of HIV. (I.e. AIDS). Due to Antiretroviral therapy medication, Some Symptoms of Rajayakshama were Suppressed likes Chardi and Aruchi.

If society and patients' relatives will given mentally and physically support to patient and provide confidence then patient can be at least mentally stable. It also affects patient's diet and Sattvic life style on immunity.

Ayurveda is best for the treatment covered on the level of mentally, physically and socially too. This is opportunity to fulfill definition of healthy person by W.H.O. After this study we can go far treatment part of AIDS which will be Rajayaksham treatment together. Sapta dhatu Vardhaka Ahara -Vihara and chikitsa, Sadwritta, Rasayana sevana, Bramhacharya, Sattvic life style etc. Rajaykshma chikitsa will be helpful to decrease symptoms of HIV or AIDS opposite from this will increase the symptoms of AIDS. Aahar, Nidra and Bramhacharaare Trayopasthambha of our body (5). Maintaining of these three pillars will be helpful for health of an Individual.

Mental illness of person is treatedby Sadvrutta Palana and Achararasayana mentioned in Charaka Samhita (6) .Ashwasana (Counselling) and Sattvavajaya Chikitsa can help to improve Mental illness in patient (7). AIDS disease have one of the very common cause observed that is bad life style. In Ayurveda Dinacharya, Rutucharya and Ratricharyawere mentioned which grip this point on physical level in this era. Due to wrong publicity and socially placed value AIDS has become more dangerous than its actual nature. Positive way awareness is needed to make patients devoid from this life-threatening disease

This study reveals that, symptoms of AIDS is resembles with Rajayakshama. AIDS is very newly found disease, so it was not mentioned in ayurvedic texts. To get rid of AIDS type of life threatening disease Ayurveda should put its role. So, symptoms which resembles with AIDS can be treated by Ayurveda limbs.

\section{Conclusion}

After this study we can conclude that, this disease is more related to mental status of the person. The person who has supported by their family and aware with this disease is not much affected with symptoms of Rajayakshma. They were physically sick and about to tapering of antiretroviral therapy. But those who have fear about society, family and personal sickness, they have many more associate diseases found. Following Dinacharya, Rutucharya, Sadvrittapalana, Aachararasayana etc. explained in Ayurveda will definitely help in treating AIDS and improving patient's health.

\section{Reference}

1. Nilam Jadhav and Manjiri S. Deshpande, a review on types of samprapti in charaka chikitsasthana, wjpps, August 2018, Vol 7, Issue 9, 674-684. https://storage.googleapis.com/journal-uploads/ wjpps/article issue/1535764872.pdf

2. Saurabh Bajïrao Kadam, Shital Rahul Rasane and Preeti Mishra, a conceptual study of symptoms of aids with ayurvedic perspective with special reference to charak samhita, WJPR, jan 2021, Volume 10, Issue 2, 412-417, https://wjpr.net/

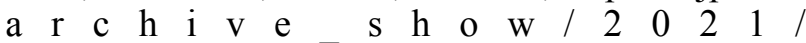
VOLUME\%20FEBRUARY\%20ISSUE\%202

3. Harish Chandra Singh Kushwaha, charaka samhita of agnivesh revised by charaka and drudhabala with ayurveddipika commentary by chakrapanidata, chikitsasthan, Reprint Edition 2016, Varanasi; Chaukhambha Orientalia publishers, 2016, Page No.222.

4. Preeti N. Malani, MD, MSJ, Human Immunodeficiency Virus,JAMA. 2016;316(2):238. https://jamanetwork.com/journals/jama/fullarticle/ 2533069

5. Ashwini B. Jaiswal, ayurveda perspective on concept of trayostambh, correlation with diseases and their management,wjpmr, 2020,6(4), 117-119, https://www.wjpmr.com/download/article/ 66032020/1585909193.pdf

6. Baid Aslesha \& Kamath M.S., role of achara rasayana - in prevention and cure the diseases, International Ayurvedic Medical Journal (IAMJ), Nov- Dec 2013, Volume 1; Issue 6; page 42-49. http://www.iamj.in/images/upload/42_49.pdf

7. Tripathi J.S., dimensions of sattvavajaya chikitsa, ayurvedic psychotherapy and their clinical applications, annals of ayurvedic medicine, Jan-Jun 2012, Vol-1 Issue-1 \& 2, page 31-38 http:// aamjournal.in/fulltext/70-1339062656.pdf 